An essential base of the central types...

DOI $10.31489 / 2021 \mathrm{M} 1 / 119-126$

UDC 510.67

\author{
A.R. Yeshkeyev*, M.T. Omarova \\ Buketov Karaganda University, Karaganda, Kazakhstan \\ (E-mail: aibat.kz@gmail.com,omarovamt_963@mail.ru)
}

\title{
An essential base of the central types of the convex theory
}

\begin{abstract}
In this paper, we consider the model-theoretical properties of the essential base of the central types of convex theory. Also shows the connection between the center and Jonsson theory in permissible enrichment signatures. Moreover, the theories under consideration are hereditary. This article is divided into 2 sections: 1) an essential types and an essential base of central types (in this case, the concepts of an essential type and an essential base are defined using the Rudin-Keisler order on the set of central types of some hereditary Jonsson theory in the permissible enrichment); 2) the atomicity and the primeness of $\varphi(x)$-sets. In this paper, new concepts are introduced: the $\varphi(x)$-Jonsson set, the $A P A$-set, the $A P A$-existentially closed model, the $\varphi(x)$-convex theory, the $\varphi(x)$-transcendental theory, the $A P A$-transcendental theory. One of the ideas of this article refers to the fact that in the work of Mustafin T.G. it was noticed that any universal model of a quasi-transcendental theory with a strong base is saturated, but we generalized this result taking into account that: the concept of quasi-transcendence will be replaced by the $\varphi(x)$-transcendence, where $\varphi(x)$ defines some Jonsson set; and the notion of a strong base is replaced by the notion of an essential base, but in a permissible enrichment of the hereditary Jonsson theory. The main result of our work shows that the number of fragments obtained under a closure of an algebraic or definable type does not exceed the number of homogeneous models of a some Jonsson theory, which is obtained as a result of a permissible enrichment of the hereditary Jonsson theory.
\end{abstract}

Keywords: Jonsson theory, central types, essential base, $\varphi(x)$-set, $\varphi(x)$-convex theory, $\varphi(x)$-transcendental theory, APA-transcendental theory, fragment.

This article is devoted to the study of the central types of a special case of the convex theory [1]. Besides, the concept of convexity is considered class of Jonsson theories [2; 80]. Many works were devoted to the study of Jonsson theories: the general properties of Jonsson theories, for example, were studied in the following papers [3-7]; results concerning various extensions of Jonsson theories, including companions, can be found in [8, 9]. When studying the properties of elements and subsets of the semantic model of the fixed Jonsson theory, many new concepts and problems related to them have arisen. First of all, it should be noted the concept of a Jonsson set, which is a generalization of the concept of a basis in a linear space. If we consider a linear space as a special case of a module, then our interest in studying various refinements of the concept of a Jonsson set becomes clear. Moreover, in $[10,11]$, related to the concept of a certain dimension, various generalizations of the well-known model-theoretic results were obtained. The concept of dimension is the cornerstone of all mathematics, and therefore finding new implementations of the ideas of dimension is an urgent task.

On the other hand, one of the classical questions of the Model Theory is the question of the spectrum of models, that is, the number of models in a particular cardinality up to isomorphism. In the study of Jonsson theories, the concept of a Jonsson spectrum was considered [12]. In this case, we have some syntactic invariant of an arbitrary model of an arbitrary signature. Namely, the number of Jonsson theories whose model is the given model under consideration up to cosemanticness [13]. It turned out that within the framework of studying the Jonsson spectrum one can consider the well-known classical question: let $K$ be a certain class of models of an arbitrary signature $\sigma$ of a first-order language $L$ and $L_{0}$ is the set of all sentences of this language, i.e. $L_{0} \subset L$ and $\Gamma \subseteq L_{0}$. If we consider the $T h_{\Gamma}(K)$ theory of the class $K$, where $T h_{\Gamma}(K)=\{\phi \in \Gamma: \forall A \in K$ follows that $A=\phi\}$ and consider the class of models of this theory $M=\operatorname{Mod}\left(T h_{\Gamma} K\right)$, then the connection between the classes $M$ and $K$ is the classical formulation of the question of the axiomatizability of the class $K$. In the case when the theory is not complete (and Jonsson theories, generally speaking, are like that), this class of problems becomes difficult enough for a complete description. Another difficulty in the study of Jonsson theories is the fact that the well-described part is only a small fraction of the class of all Jonsson theories of the fixed signature. And

\footnotetext{
${ }^{*}$ Corresponding author.

E-mail: aibat.kz@gmail.com
} 
this part of the class in question consists of a union of classes consisting of perfect Jonsson theories. That is theories that have a model companion and their class of existentially closed models satisfy the above classical problem of axiomatizability of this class.

The concept of the central type is associated with the concept of hereditary enrichment in Jonsson's theory $[14,15]$. The concept of heredity at the moment does not have a complete description, except for some intuitive guesses. We took one of them from the ideas of constructing a pregeometry [16] on the Boolean of the semantic model of a fixed Jonsson theory. The next idea relates to the fact that in [17] it was noted that the saturation of any universal model of quasi-transcendental theory with a strong base, as well as, the superstability of such theories (Theorem 2).

In this paper, the notion of quasi-transcendence will be replaced by $\varphi(x)$-transcendence, where $\varphi(x)$ defines some Jonsson set $[13 ; 278]$, and the notion of a strong base is replaced by the notion of an essential base but in permissible enrichment of the hereditary Jonsson theory.

\section{An essential types and an essential base of central types}

Before we give the necessary definitions, we recall how we get the central type.

Let $L$ be a first-order language, $T$ be an arbitrary hereditary Jonsson theory in $L$ of the signature $\sigma, C$ be a semantic model of the theory $T, A \subseteq C, \sigma^{\prime}=\sigma \bigcup\{P\} \bigcup\{c\}$.

Let $\bar{T}=T \bigcup T h_{\forall \exists}\left(C, c_{a}\right)_{a \in A} \bigcup\{P(c)\} \bigcup\{P, \subseteq\}$, where $\{P, \subseteq\}$ is an infinite set of sentences expressing the fact that the interpretation of the symbol $P$ is an existentially closed submodel in the language of signature $\sigma^{\prime}$. That is, the interpretation of the symbol $P$ is a solution to the following equation $P(C)=M, M \in E_{T}$ in the language of the signature $\sigma^{\prime}$.

Since we know an example of the fact that the Jonsson theory in enrichment with a unary predicate does not preserve the property of amalgam, and the central type is obtained from the center of the Jonsson theory in the enriched language, we need the following definitions.

Definition 1. An enrichment $\bar{T}$ of the Jonsson theory $T$ is said to be permissible if any $\nabla$-type (it mean that $\nabla$ subset of language $L_{\sigma}$ and any formula from this type belongs to $\nabla$ ) in this enrichment is definable in the framework of $\bar{T}_{\Gamma \text {-stability. }}$

Definition 2. The Jonsson theory is said to be hereditary, if in any of its permissible enrichment, it preserves the Jonssonness.

Consider all extensions of the theory $\bar{T}$ in the language of signature $\sigma^{\prime}$. Since $T$ is a hereditary theory, then $\bar{T}$ will be a Jonsson theory, so it has a center, and we denote it by $\bar{T}^{*}$, and this center is equal to one of above completions theory $\bar{T}$. When restricting the signature $\sigma^{\prime}$ to $\sigma \cup\{P\}$, according to the laws of first-order logic, the constant $c$ no longer belongs to this signature, and we can replace this constant with a variable, for example, $x$. And then the theory $\bar{T}^{*}$ becomes a complete 1-type for the variable $x$. We will call this type the central type of the theory $\bar{T}$ in the above enrichment.

In what follows, we define the concept of an essential type and an essential base using the Rudin-Keisler order on the set of central types of some hereditary Jonsson theory in a permissible enrichment.

Definition 3. Type $p \in S_{\nabla}^{(1)}(X)$ is called essential if for any set $Y, Y \subseteq N, N \in E_{T}$, such that $X \subseteq Y$ in $T$ exists only unique type $q \in S_{\nabla}^{(1)}(Y)$ and the type $q$ is a $J$-nonforking extension of type $p$.

Let $p, q \in S_{\nabla}^{(1)}(X), \mathfrak{A} \in E_{T}$ and $X \subseteq A$. The relation $p \leq_{A} q$ is means that for any model $\mathfrak{B} \in E_{T}$, such that $\mathfrak{B} \supseteq \mathfrak{A}$, from the realizability of $q$ in $B \backslash A$ implies the realizability of $p$ in $B \backslash A$. The relation $p \equiv q$ means that for any model $\mathfrak{A} \in E_{T}, X \subseteq A$, has $p \leq_{A} q$ and $q \leq_{A} p$. We denote the set $\left\{q \mid q \in S_{\nabla}^{(1)}(X), p \equiv q\right\}$ by $[p]$, and the set $\left\{[p] \mid p \in S_{\nabla}^{(1)}(X)\right\}$ denote by $S_{\nabla}^{(1)}[X]$. We write $[p] \leq_{A}[q]$, if $p \leq_{A} q$. The types $p, q$ are called independent if for any $\mathfrak{A} \in E_{T}, X \subseteq A$, don't have a place neither $p \leq_{A} q$, nor $q \leq_{A} p$. If $p$ and $q$ are independent, then we say that $[p]$ and $[q]$ are independent.

The following definition gives the concept of a basis among the above types.

Definition 4. The set $B=\left\{\left[p_{i}\right] \in S_{\nabla}^{(1)}[X] \mid i \in I\right\}$ is called base for $S_{\nabla}^{(1)}[X]$ if:

(1) $\left[p_{i}\right]$ and $\left[q_{j}\right]$ independent for $i \neq j$;

(2) for any $[q] \in S_{\nabla}^{(1)}[X]$ and $\mathfrak{A} \in E_{T}, X \subseteq A$, exists $i \in I$, such that $\left[p_{i}\right] \leq_{A}[q]$.

Definition 5 . The base of the theory $T$ is the base for $S_{\nabla}^{(1)}[\varnothing]$ (if it exists). The base $B$ of $T$ is called essential if for any $[p] \in B$ exists an essential type $q \in[p]$.

Let us define the notion of pregeometry on the Boolean of subsets of the semantic model of a fixed Jonsson theory $T$. 
Let $T$ be a some Jonsson theory, $C$ be its semantic model.

Definition 6 . Let $C$ be as above and let cl: $P(C) \rightarrow P(C)$ be an operator on the power set of $C$. We say that $(C, c l)$ is a pregeometry if the following conditions are satisfied:

i) if $A \subseteq C$, then $A \subseteq \operatorname{cl}(A)$ and $\operatorname{cl}(\operatorname{cl}(A))=\operatorname{cl}(A)$.

ii) if $A \subseteq B \subseteq C$, then $\operatorname{cl}(A) \subseteq \operatorname{cl}(B)$.

iii)(exchange) if $A \subseteq C, a, b \in C$ and $a \in \operatorname{cl}(A \cup\{b\})$, then $a \in \operatorname{cl}(A), b \in \operatorname{cl}(A \cup\{a\})$.

iv)(finite character) if $A \subseteq C$ and $a \in \operatorname{cl}(A)$, then there is a finite $A_{0} \subseteq A$ such that $a \in \operatorname{cl}\left(A_{0}\right)$.

We say that $A \subseteq C$ is closed if $\operatorname{cl}(A)=A$.

In particular, we can define the notion of strong minimality on formula subsets of existentially closed submodels of the semantic model of a fixed Jonsson theory [13].

If $D$ is strongly minimal, we can associate a pregeometry by defining $\operatorname{cl}(A)=\operatorname{acl}(A) \cap D$ for $A \subseteq D$.

We can generalize basic ideas about independence and dimension from strongly minimal sets to arbitrary pregeometries for any subset of fix semantic model of some Jonsson theory.

Let as call $(X, c l$ )-Jonsson pregeometry (further $J$-pregeometry) if $X \subseteq C, C$ and $T$ as above.

Definition \%. If $(X, c l)$ is a Jonsson pregeometry, we say that $A$ is Jonsson independent if $a \notin \operatorname{cl}(A \backslash\{a\})$ for all $a \in A$ and that $B$ is a $J$-basis for $Y$ if $B \subseteq Y$ is $J$-independent and $Y \subseteq \operatorname{acl}(B)$.

Definition 8. We say that a $J$-pregeometry $(X, c l)$ is $J$-geometry if $c l(\emptyset)=\emptyset$ and $\operatorname{cl}(\{x\})=\{x\}$ for any $x \in X$.

If $(X, c l)$ is a $J$-pregeometry, then we can naturally define a $J$-geometry. Let $X_{0}=X \backslash \operatorname{cl}(\emptyset)$. Consider the relation $\sim$ on $X_{0}$ given by $a \sim b$ iff $\operatorname{cl}(\{a\})=\operatorname{cl}(\{b\})$. By exchange, $\sim$ is an equivalence relation. Let $\widehat{X}$ be $X_{0} / \sim$. Define $\widehat{c l}$ on $\widehat{X}$ by $\widehat{c l}(A / \sim)=\{b / \sim: b \in \operatorname{cl}(A)\}$.

Definition 9. Let $(X, c l)$ be $J$-pregeometry. We say that $(X, c l)$ is trivial if $c l(A)=Y_{a \in A} c l\{a\}$ for any $A \subseteq X$. We say that $(X, c l)$ is modular if for any finite-dimensional closed $A, B \subseteq X$

$$
\operatorname{dim}(A \cup B)=\operatorname{dim} A+\operatorname{dim} B-\operatorname{dim}(A \cap B)
$$

Definition 10 . We say that $(X, c l)$ is locally modular if $\left(X, c l_{a}\right)$ is modular for some $a \in X$.

Definition 11. If $X=C$ and $(X, c l)$ is a modular, then the Jonsson theory $T$ is called modular.

Let in what follows the operator $c l$ is either an algebraic or a definable closure of some $\varphi(x)$-set, that is, if $C$ is a semantic model of some Jonsson theory, and $\varphi(C)=A$, then $\operatorname{cl}(A)=M \in E_{T}, M=M_{1} \cup M_{2}, M_{1}=a c l(A)$, $M_{2}=\operatorname{dcl}(A)$.

Definition 12. Let $X \subseteq C$. We will say that a set $X$ is $\nabla$-cl-Jonsson subset of $C$, if $X$ satisfies the following conditions:

1) $X$ is $\nabla$-definable set (this means that there is a formula from $\nabla$, the solution of which in the $C$ is the set $X$, where $\nabla \subseteq L$, that is $\nabla$ is a view of formula, for example $\exists, \forall, \forall \exists$ and so on.);

2) $c l(X)=M, M \in E_{T}$, where $c l$ is some closure operator defining a pregeometry over $C$ (for example $c l=a c l$ or $c l=d c l)$.

It is clear that the $\varphi(x)$-Jonsson set is a special case of Definition 12, i.e. these are elements of the semantic model that are solutions of the formula $\varphi(x)$ in the model $C$.

And in particular, $\varphi(x)$-set is called a $\varphi(x)$-Jonsson set in the theory $T$ if the following definition holds.

Definition 13. Let $X \subseteq C$. We will say that a set $X$ is $\varphi(x)$-Jonsson subset of $C$, if $X$ satisfies the following conditions:

1) $X$ is $\varphi(x)$-definable set (this means that there is a formula from $\varphi(x)$, the solution of which in the $C$ is the set $X$, where $\varphi(x) \subseteq L$, that is $\varphi(x)$ is a view of formula $\exists$ );

2) $\operatorname{cl}(X)=M, M \in E_{T}$, where $c l$ is some closure operator defining a pregeometry over $C$ (for example $c l=a c l$ or $c l=d c l)$.

Any subset of the semantic model is called the set $X$ in the Jonsson theory $T$.

\section{The atomicity and the primeness of $\varphi(x)$-sets}

A model-theoretical property of a model is said to be an $A P A$-property if it satisfies the properties of algebraic primeness and atomicity in the sense of [18]. For example, let us give an important definition of $A P A$-transcendence.

Definition 14. A set $X$ is called an $A P A$-set if it is $\varphi(x)$-Jonsson set and $M$ is algebraically prime and $\left(\Sigma_{1}, \Sigma_{1}\right)$-atomic model, where $M=\operatorname{cl}(X), M \in E_{T}$. And in this case the model $M$ is called an $A P A$-existentially closed model. 
And accordingly, an analog of the quasi-transcendental theory from [17] is the notion of the $A P A$-transcendental theory.

Definition 15. A Jonsson theory $T$ is called $A P A$-transcendental, if for any $A P A$-set of the $X$ in the theory $T$ there exist $A P A$-existentially closed model $M$, such that $\operatorname{cl}(X)=M$.

We recall the classical definition of a convex theory belongs to A. Robinson.

Definition 16. A theory $T$ is called convex if for any its model $A$ and for any family $\left\{B_{i} \mid i \in I\right\}$ of substructures of $A$, which are models of the theory $T$, the intersection $\bigcap_{i \in I} B_{i}$ is a model of $T$, provided it is non-empty. If in addition such an intersection is never empty, then $T$ is called strongly convex.

The following definition selects a rather interesting subclass in the class of convex Jonsson theories, which is defined by the closure of some formula $\varphi(x)$.

Definition 17. The theory $T$ will be called $\varphi(x)$-convex if:

1) it is convex in the classical sense;

2) for any existentially closed model $N$ of this theory, there is a theoretical set $A$ such that $\operatorname{cl}(A)=\cap_{i} B_{i}$, $B_{i} \prec_{\Sigma_{1}} N$ and exists $\varphi(x): \varphi(C)=A$.

Let $C$ be semantic model, $M_{i} \prec C, i \in I$. There are 2 possible cases.

1 case. $M_{i}$ are existentially closed models.

2 case. $M_{i}$ are not existentially closed models. Then, by the Lowenheim-Sculem up theorem, there exist elementary extensions $M_{i}^{\prime} \succ M_{i}$, which, according to Proposition $8.12[2 ; 97]$ will already be existentially closed models.

This means that in any case, there are models $M_{i}$ that will be existentially closed.

Summarizing the above, we can consider a more general situation, defining the next class of theories.

Definition 18. Let $T$ be the Jonsson theory. $T$ is called the $\varphi(x)$-transcendental if on any $\varphi(x)$-set there is $\left(\nabla_{1}, \nabla_{2}\right)$-atomic and $h$-prime model, where $\nabla_{1}, \nabla_{2} \subset L$ and $h$ is an arbitrary homomorphism between the models of the theory $T$.

We denote $\operatorname{Th}{ }_{\forall \exists}(M)$ by $\operatorname{Fr}(A)$ and call it a fragment of the Jonsson theory $T$, where $C$ is the semantic model of this theory, $A \subseteq C, M=\operatorname{cl}(A), M \in E_{T}$.

The following theorem is the main result of this article. This theorem shows that the number of fragments obtained under a closure of an algebraic or definable type does not exceed the number of homogeneous models of some Jonsson theory, which is obtained as a result of a permissible enrichment of the hereditary Jonsson theory.

Theorem. Let $T$ be hereditary, complete for $\exists$-sentences, $\varphi(x)$-convex, $\varphi(x)$-transcendental Jonsson theory with an essential base of central types in its fragments, where $\varphi(x)$ defines a $A P A$-subset of the semantic model $C$. Then there is a cardinal $\mu$ such that the number of fragments is determined by the following formula

$$
H(\alpha, \bar{T})= \begin{cases}1, & \text { at condition } I=1 \& \alpha>0 \\ \aleph_{0}^{\min \left(\mu, \aleph_{\alpha}\right)}, & \text { in other cases. }\end{cases}
$$

where $H(\alpha, \bar{T})$ is the number of homogeneous models of the theory $\bar{T}$.

Proof. Consider the enrichment of the language of the theory $T$ with a new constant symbol $c$ and a new unary predicate symbol $p$. Let us write one of the completions of the theory $T$ in the following form:

$$
\bar{T}=T \bigcup T h_{\forall \exists}\left(C, c_{a}\right)_{a \in A} \bigcup\{P(c)\} \bigcup\{P, \subseteq\} .
$$

Let $\{P, \subseteq\}$ be the set of sentences defining the $N$ model,where $N \in E_{T}, N$ is the core, $\left(\Sigma_{1}, \Sigma_{1}\right)$-atomic model. Such a model exists due to $\varphi(x)$-convexity of the theory $T$. Consider all existentially closed extensions of the model $N$. It is easy to see that the class of all these extensions does not exceed $E_{T}$. Moreover, due to the convexity of the theory $T$, this class coincides with $E_{T}$. To count the number of models $E_{T}$, we will use the central type technique. Let $M_{i}$ be an arbitrary existentially closed extension of the model $N$. Consider the central type of models $M_{i}$. To do this, we will consider the fragments $T h_{\forall \exists}\left(M_{i}\right)$, denote them $T_{i}$. This is a Jonsson theory in the language of the theory $T$, since $M_{i} \in E_{T}$. Consider

$\bar{T}_{M_{i}}=T \bigcup T h_{\forall \exists}\left(C_{\uparrow M_{i}}, c_{a}\right)_{a \in A} \bigcup\{P(c)\} \bigcup\left\{P_{M_{i}}, \subseteq\right\}$, where $\left\{P_{M_{i}}, \subseteq\right\}$ is a set sentences reflecting the fact that $N \preceq \Sigma_{1} M_{i}$. Due to the heredity of the $T_{i}$ theory, the theory $\bar{T}_{M_{i}}$ is a Jonsson theory, and it has a corresponding center, we denote it $\bar{T}_{M_{i}}^{*}$. By virtue of the laws of first-order logic, we can replace the constant symbol $c$ with the symbol of the variable $x$, if in the new language we will leave only the predicate symbol $P$. Then instead of the center $\bar{T}_{M_{i}}^{*}$ we get some complete type in the old language with the predicate symbol $P$. Let's denote this type by $p_{M_{i}}^{c}$. This is the central type of the theory $\bar{T}_{M_{i}}$. 
There will be as many such central types as there are $M_{i}$ models. On this set of central types, i.e. obtained for each model $M_{i} \in E_{T}$, we consider the essential base of essential central types. And concerning it we use the results of Theorems 1 and 2 from [17]; in the language of central types, this means that each $T_{i}$ is a perfect Jonsson theory, since Theorem 2 proved the saturation of the universal model for a quasi-transcendental theory with a strong base. Each semantic model of Jonsson theory is universal in the sense of isomorphic embedding and relative to $\exists$-formulas, and due to the $\exists$-completeness of the $T$ theory, we can transfer the proof of saturation for $\exists$-types. This means that the theories $T_{i}$ are perfect Jonsson theories, due to heredity, $\bar{T}_{M_{i}}$ are also perfect Jonsson theories, so their centers are model complete, which means that all embeddings between models are elementary. In particular, all algebraically prime models are prime models, and $\left(\Sigma_{1}, \Sigma_{1}\right)$-atomic models are atomic models of the theory $\bar{T}_{M_{i}}^{*}$. Therefore, there will be as many central types as there are semantic models of theories $T_{i}$, but all these models are existentially closed models, like the semantic models of Jonsson theories. By virtue of the perfectness of Jonsson's theory $\overline{T_{i}}$, the class $E_{\overline{T_{i}}}$ is equivalent to the class $\operatorname{Mod} \bar{T}_{i}^{*}$. Because of the above, we can conclude that the number of central types for the Jonsson theory is exactly equal to the number of universally homogeneous models, and we can apply the result of Theorem 6 from [17], concerning only the spectrum of homogeneous models, which uniquely determines the criterion for the Jonsson theory, namely, a theory is Jonsson if and only if it has a universally homogeneous model of sufficient power.

\section{Acknowledgments}

This work was supported by the Science Committee of the Ministry of Education and Science of the Republic of Kazakhstan (grant AP09260237).

\section{References}

1 Kueker D.W. Core structures for theories / D.W. Kueker // Fundamenta Mathematicae LXXXIX. 1973. - P. 154-171.

2 Barwise J.Ed., Handbook of mathematical logic. - Part 1, Model Theory / J. Barwise. - Moscow: Science, 1982.

3 Yeshkeyev A.R. del-cl-atomic and prime sets / A.R. Yeshkeyev, A.K. Issayeva // Bulletin of the Karaganda University - Mathematics. — 2019. — 93. — № 1. - P. 88-94. DOI: 10.31489/2019M1/88-94

4 Yeshkeyev A.R. The Properties of Similarity for Jonsson's Theories and Their Models / A.R. Yeshkeyev // Bulletin of the Karaganda University. Mathematics series. - 2015. — 80. — № 4. - P. 52-59.

5 Yeshkeyev A.R. The atomic definable subsets of semantic model / A.R. Yeshkeyev, N.M. Mussina, A.K. Issayeva // Bulletin of the Karaganda University. Mathematics series. - 2019. - 94. - № 2. P. 84-91. DOI 10.31489/2019M2/84-91

6 Yeshkeyev A.R. Properties of hybrids of Jonsson theories/ A.R. Yeshkeyev, N.M. Mussina // Bulletin of the Karaganda University. Mathematics series. — 2018. - 92. — № 4. - P. 99-104. DOI: 10.31489/2018M4 /99-104

7 Yeshkeyev A.R. The properties of central types with respect to enrichment by Jonsson set / A.R. Yeshkeyev // Bulletin of the Karaganda University. Mathematics series. — 2017. — 85. — № 1. P. 36-40. DOI: $10.31489 / 2017 \mathrm{M} 1 / 36-40$

8 Yeshkeyev A.R. Companions of the fragments in the Jonsson enrichment / A.R. Yeshkeyev // Bulletin of the Karaganda University. Mathematics series. — 2017. — 85. — № 1. - P. 41-45. DOI: 10.31489/2017M1 /41-45

9 Yeshkeyev A.R. Companions of $(\mathrm{n}(1), \mathrm{n}(2))$-Jonsson theory / A.R. Yeshkeyev, M.T. Omarova // Bulletin of the Karaganda University. Mathematics series. - 2019. - 96. - № 4. - P. 75-80. DOI 10.31489/2019M4 75-80

10 Ешкеев A.P. JSp-косемантичность и $J S B$-свойство абелевых групп [Электронный ресурс] / A.Р. Ешкеев, О.И. Ульбрихт // Siberian Electronic Mathematical Reports. - 2016. - 13. - C. 861-874. Режим доступа: http://semr.math.nsc.r. Doi: 10.17377/semi.2016.13.068

11 Ешкеев A.P. JSp-косемантичность $R$-модулей [Электронный ресурс] / A.Р. Ешкеев, О.И. Ульбрихт // Siberian electronics mathematical reports. - 2019. - 16. - C. 1233-1244. Режим доступа: http: //semr.math.nsc.ru DOI: 10.33048/semi.2019.16.084 
12 Yeshkeyev A.R. Model-theoretical questions of the Jonsson spectrum / A.R. Yeshkeyev // Bulletin of the Karaganda University. Mathematics series. - 2020. - 98. — № 2. - P. 165-173. DOI: 10.31489/2020M2 /165-173

13 Ешкеев А.Р. Йонсоновские теории и их классы моделей: моногр. / А.Р. Ешкеев, М.Т. Касыметова. - Караганда: Изд-во КарГУ, 2016. - 370 с.

14 Yeshkeyev A.R. The J-minimal sets in the hereditary theories / A.R. Yeshkeyev, M.T. Omarova, G.E. Zhumabekova // Bulletin of the Karaganda University. Mathematics series. - 2019. - 94. - № 2 . - P. 92-98. DOI 10.31489/2019M2/92-98

15 Yeshkeyev A.R. Central types of convex fragments of the perfect Jonsson theory / A.R. Yeshkeyev, M.T. Omarova // Bulletin of the Karaganda University. Mathematics series. - 2019. - 93. - № 1 . P. 95-101. DOI 10.31489/2019M1/95-101

16 Yeshkeyev A.R. Small models of hybrids for special subclasses of Jonsson theories / A.R. Yeshkeyev, N.M. Mussina // Bulletin of the Karaganda University. Mathematics series. — 2019. — 95. - № 3. P. 68-73. DOI 10.31489/2019M2/68-73

17 Мустафин Т.Г. О сильной базе элементарных типов теорий / Т.Г. Мустафин // Сиб. матем. журн. - 1977. - 18. - № 6. - C. 1356-1966.

18 Baldwin J.T. Algebraically prime models / J.T. Baldwin, D.W. Kueker // Ann. Math. Logic. - 1981. 20. - P. 289-330.

\title{
А.Р. Ешкеев, М.Т. Омарова
}

\section{Дөңес теорияның централдық типтерінің елеулі базасы}

\begin{abstract}
Мақалада дөңес теорияның централдық типтерінің елеулі базасының модельді-теоретикалық қасиеттері қарастырылған. Рұқсат етілген байытылған сигнатурада центр мен йонсондық теорияның байланысы көрсетілген. Сонымен қатар қарастырылып отырған теориялар мұралы теориялар болып табылады. Осы жұмыс 2 параграфқа бөлінген: 1) елеулі типтер және централдық типтердің елеулі базасы (сонымен бірге елеулі тип пен елеулі база ұғымдары Рудин-Кейслердің реті арқылы анықталады, яғни кейбір мұралы йонсондық теорияның рұқсат етілген байытуында централдық типтердің жиынында); 2) $\varphi(x)$ - жиынның атомдығы және жайлылығы. Келесі жаңа ұғымдар енгізілген: $\varphi(x)$ - йонсондық жиын, $A P A-$ жиын, $A P A-$ экзистенционалды тұйық модель, $\varphi(x)-$ дөңес теория, $\varphi(x)$ - трансцендентті теория, $A P A-$ трансцендентті теория. Осы мақаланың бір идеясы Т.Ғ. Мұстафиннің еңбегінде квазитрансцендентті теорияның кез-келген әмбебап моделі қатты базамен қаныққан екендігі деп атап өтілген деген дерекке қатысты, бірақ мақала авторлары бұл нәтижені ескере отырып жалпылау жасады: квазитрансценденттілік ұғымы $\varphi(x)$-трансценденттілікке ауыстырылды, мұндағы $\varphi(x)$ кейбір йонсондық жиынды анықтайды; және қатты база ұғымы елеулі база ұғымымен алмастырылды, бірақ мұралы йонсондық теорияның рұқсат етілген байытуында. Жұмыстың негізгі нәтижесі көрсеткендей, алгебралық немесе анықталатын типтің тұйықталуы кезінде алынған фрагменттер саны мұралы йонсондық теорияның рұқсат етілген байыту нәтижесінде алынған кейбір йонсондық теорияның біртекті модельдерінің санынан аспайды.
\end{abstract}

Kiлm сөздер: йонсондық теория, централдық типтер, елеулі база, $\varphi(x)$-жиын, $\varphi(x)$-дөңес теория, $\varphi(x)$ трансцендентті теория, $A P A$-трансцендентті теория, фрагмент.

\section{А.P. Ешкеев, М.Т. Омарова}

\section{Существенная база центральных типов выпуклой теории}

В статье рассмотрены теоретико-модельные свойства существенной базы центральных типов выпуклой теории. Показаны связи между центром и йонсоновской теорией в разрешенном обогащении сигнатуры. При этом рассматриваемые теории являются наследственными. Данная работа разбита на 2 параграфа: 1) существенные типы и существенная база центральных типов (при этом понятия существенного типа и существенной базы определяются с помощью порядка Рудина-Кейслера на 
множестве центральных типов некоторой наследственной йонсоновской теории в разрешенном обогащении); 2) атомность и простота $\varphi(x)$-множеств. Введены новые понятия: $\varphi(x)$ - йонсоновское множество; $A P A-$ множество; $A P A$ - экзистенциально замкнутая модель; $\varphi(x)$ - выпуклая теория; $\varphi(x)$ - трансцендентная теория; $A P A$ - трансцендентная теория. Одна из идей данной статьи относится к тому факту, что в работе Т.Г. Мустафина было замечено, что любая универсальная модель квазитрансцендентной теории с сильной базой насыщена. Авторы статьи обобщили этот результат с учетом того, что понятие квазитрансцендентности будет заменено $\varphi(x)$-трансцендентностью, где $\varphi(x)$ задает некоторое йонсоновское множество; а понятие сильной базы заменено понятием существенной базы, но в разрешенном обогащении наследственной йонсоновской теории. Главный результат данной работы показывает, что число фрагментов, полученных под замыканием алгебраического или определимого типа, не превосходит числа однородных моделей некоторой йонсоновской теории, которая получается в результате разрешенного обогащения наследственной йонсоновской теории.

Ключевые слова: йонсоновская теория, центральные типы, существенная база, $\varphi(x)$-множество, $\varphi(x)$ выпуклая теория, $\varphi(x)$-трансцендентная теория, $A P A$-трансцендентная теория, фрагмент.

\section{References}

1 Kueker, D.W. (1973). Core structures for theories. Fundamenta Mathematicae LXXXIX, 154-171.

2 Barwise, J. (1982). Ed., Handbook of mathematical logic. Part 1, Model Theory. Moscow, Science.

3 Yeshkeyev, A.R., \& Issayeva, A.K. (2019). del-cl-atomic and prime sets. Bulletin of the Karaganda University - Mathematics, 93(1), 88-94. DOI: 10.31489/2019M1/88-94

4 Yeshkeyev, A.R. (2015). The Properties of Similarity for Jonsson's Theories and Their Models. Bulletin of the Karaganda University - Mathematics, 80(4), 52-59.

5 Yeshkeyev, A.R., Issayeva, A.K., \& Mussina, N.M. (2019). The atomic definable subsets of semantic model. Bulletin of the Karaganda University - Mathematics, 94(2), 84-91.

DOI 10.31489/2019M2/84-91

6 Yeshkeyev, A.R., \& Mussina, N.M. (2018). Properties of hybrids of Jonsson theories. Bulletin of the Karaganda University - Mathematics, 92(4), 99-104. DOI: 10.31489/2018M4/99-104

7 Yeshkeyev, A.R. (2017). The properties of central types with respect to enrichment by Jonsson set. Bulletin of the Karaganda University - Mathematics, 85(1), 36-40. DOI: 10.31489/2017M1/36-40

8 Yeshkeyev, A.R. (2017). Companions of the fragments in the Jonsson enrichment. Bulletin of the Karaganda University - Mathematics, 85(1), 41-45. DOI: 10.31489/2017M1/41-45

9 Yeshkeyev, A.R., \& Omarova, M.T. (2019). Companions of $(\mathrm{n}(1), \mathrm{n}(2))$-Jonsson theory. Bulletin of the Karaganda University - Mathematics, 96(4), 75-80. DOI 10.31489/2019M4/75-80

10 Yeshkeyev, A.R., \& Ulbrikht, O.I. (2016). JSp-kosemantichnost i $J S B$-svoistvo abelevykh hrupp [JSp-cosemanticness and JSB property of Abelian groups]. Sibirskie elektronnye matematicheskie izvestiia - Siberian Electronic Mathematical Reports, 13, 861-874 [in Russian].

11 Yeshkeyev, A.R., \& Ulbrikht, O.I. (2019). JSp-kosemantichnost $R$-modulei [JSp-cosemanticness of R-modules]. Sibirskie elektronnye matematicheskie izvestiia - Siberian Electronic Mathematical Reports, 16, 1233-1244. Doi: 10.33048/semi.2019.16.084 [in Russian].

12 Yeshkeyev, A.R. (2020). Model-theoretical questions of the Jonsson spectrum. Bulletin of the Karaganda University - Mathematics, 98(2), 165-173. DOI: 10.31489/2020M2/165-173

13 Yeshkeyev, A.R., \& Kassymetova, M.T. (2016). Yonsonovskie teorii i ikh klassy modelei /Jonsson theories and their classes of models]. Karaganda: Izdatelstvo Karahandinskoho universiteta [in Russian].

14 Yeshkeyev, A.R., Omarova, M.T., \& Zhumabekova, G.E. (2019). The J-minimal sets in the hereditary theories. Bulletin of the Karaganda University - Mathematics, 94 (2), 92-98. DOI 10.31489/2019M2/92-98

15 Yeshkeyev, A.R., \& Omarova, M.T. (2019). Central types of convex fragments of the perfect Jonsson theory Bulletin of the Karaganda University - Mathematics, 93(1), 95-101.

DOI $10.31489 / 2019 \mathrm{M} 1 / 95-101$

16 Yeshkeyev, A.R., \& Mussina, N.M. (2019). Small models of hybrids for special subclasses of Jonsson theories Bulletin of the Karaganda University - Mathematics, 95(3), 68-73.

DOI $10.31489 / 2019 \mathrm{M} 2 / 68-73$ 
17 Mustafin, T.G. (1977). O silnoi baze elementarnykh tipov teorii [On a strong base of elementary types of theories]. Sibirskii matematicheskii zhurnal, 18(6), 1356-1966 [in Russian].

18 Baldwin, J.T., \& Kueker, D.W. (1981). Algebraically prime models. Ann. Math. Logic., 20, 289-330. 